\title{
Implementation of Nadhir Online Registration System in Badan Wakaf Indonesia Using Agile Development Methods
}

\author{
Muhammad Chamdani Sukron', Rizqi Putri Nourma Budiarti2 ${ }^{*}$, Ahmad Syafiq \\ Kamil $^{2}$
}

${ }^{1}$ S1 Sistem Informasi, Fakultas Teknik, Universitas Nahdlatul Ulama Surabaya, Surabaya

${ }^{2}$ Information System, Engineering Department, Universitas Nahdlatul Ulama Surabaya, Surabaya

*Corresponding Author

E-mail: hamdani.if16@student.unusa.ac.id ${ }^{1}$,rizqi.putri.nb@unusa.ac.id*

\begin{abstract}
The Indonesian Waqf Board is an independent state institution formed under law number 41 of 2004 concerning endowments. At present, Nadhir registration service activities at the Indonesian Waqf Board are still carried out offline, which causes Nadhir registration service activities to be inefficient and take a long time. From the above problems the authors make research "Implementation of the Nadhir Online Registration System Using Agile Development Methods" which can help the Indonesian Waqf Board in nadhir registration activities in the Indonesian Waqf Board. This research uses agile development methods that focus on personal interactions, software functionality, collaboration with clients, responses to change. The results based on experiment are in the form of a website-based nadhir registration information system that features online registration, file upload, disposition, file verification, recommendations, approving and printing certificates that can help the process of registering Nadhir in Indonesian Waqf Board .System test results obtained from the usability variable of $82 \%$ so it can be concluded that the system is feasible to use.
\end{abstract}

Keywords: Implementation, Information Systems, Online Registration, Nadhir, Indonesian Waqf Board

\section{INTRODUCTION}

In the era of digital industry 4.0 , the development of the internet has greatly increased with various innovations that focus on the internet of everything. This development is needed for innovations related to Islamic Charitable sources, especially waqf. Some studies, such as Muhammad Hakimi Bin Mohd Shafiai, 2014. which describe that Islamic Charitable Sources (zakat, waqf) very provide significant benefits and help the government to fight rural poverty [1]. Besides, in a study by Fahmi Medias, 2010. explain some of the benefits associated with waqf contain many positive aspects for the community including caring for the needs of the community such as programs contained in waqf institutions in Indonesia in providing benefits in terms of economic and social potential, helping to develop infrastructure in both worships, the world of education such as schools, health such as the construction of hospitals, housing for the community in the long term [2]. For example, the results of the management of waqf funds provide many great benefits, especially in the field of education and health under the management of the Indonesian Waqf Board [3], where waqf funds are intended for the general public because waqf assets cannot be sold or bequeathed.

With this digital era, a lot of information related to zakat, alms, and waqf is available through social media. However, public awareness and information related to procedural waqf are very 
minimal in Indonesia. Lack of knowledge and learning media related to waqf is very much needed by Indonesian people because most people in Indonesia are Muslims. Even so, In Indonesia, the activity of waqf has increased tremendously in Muslim communities. Therefore, various innovations including waqf platforms are needed especially for administrative process problems that are often faced by Nadhir who want to register for the waqf administration process, which often takes a long time to process. Therefore, as a first step, a platform that can provide knowledge about waqf is even needed, it can even explain procedurally how the registration process to become Nadhir waqf, database management related to the management of waqf properties is very necessary for transparency of the process to the public, making it easier for the community to register from anywhere via the internet.

The Indonesian Waqf Board is an independent state institution formed under Law Number 41 of 2004 concerning Waqf. This institution was formed to develop and advance membership in Indonesia. Currently, nadhir registration activities at the Indonesian Waqf Board are still done manually. In the process of collecting files that have been sent which will be selected in the form of documents that require a long time to do file selection manually. The selection process must go through the interview stage which is conducted by coming to the Head Office so that it requires a large fee.

The main purpose of this problem is to assist the Indonesian Waqf Board in Nadhir registration activities. so, we create Implementation of Nadhir Online Registration System in Badan Wakaf Indonesia Using Agile Development Methods. Agile development methods have several models including extreme programming (XP), Scrums, Adaptive Software Development (ASD). The implementation of this Nadhir registration system which is the object of research found rapid changes so that it cannot directly meet the needs that must be met so the most suitable model used in this study is the agile system development model.

According to Pressman, 2010., Agile Development Methods is a software development methodology based on iterative development, in which the requirements and solutions for development through collaboration between organized team [4]. In Agile development, the process carried out has its characteristic and the same goal is to avoid processes that work based on time, document pressure and plan stages [5].

Nadhir is the person in charge of maintaining and managing waqf. Nadhir has an important position in representation so that the functioning of the waqf for mauquf 'alaih is very dependent on nadhir waqf. In general, the ulama agree that the power of Nadhir waqf is only limited to the management of waqf to be used in accordance with the waqf objectives desired by the waqf. This proves that Nadhir is very necessary for waqf objects in achieving waqf goals [6].

An information system is a system that consists of a collection of system components, namely software, hardware, and brainware that processes information into an output that is useful for achieving a particular goal in an organization [7]. Information systems consist of five resources known as information system components [8]. The five resources are human, hardware, software, data, and network. These five components play a very important role in an information system. The use of information systems in the era of the internet of things is very necessary in the development of technology for example for the manufacture of platforms such as building smart trash web application platforms [9], Integrated Deep Learning Web Platforms [10], IoT platforms for Automated Water Quality Monitoring Systems [11] Therefore, a web platform for Nadhir registration is needed to simplify the registration and transparency of waqf activities. 


\section{RESEARCH METHODS}

In this research, it is necessary to develop a system, so that users feel comfortable in running the system to be used. Development of computer-based information systems to solve organizational problems or take advantage of opportunities that arise. The research methodology carried out by the author is depicted in Figure 1.

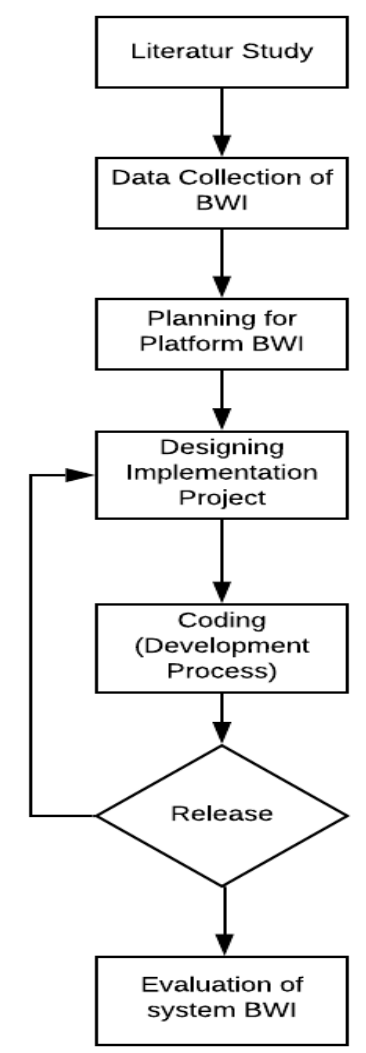

Figure 1. Research Methods

\subsection{Literature Study}

In this process, discussion is collected on journals, theses, and the internet to dig deeper into the initial idea. In addition, researchers are looking for references on Agile Development Methods.

\subsection{Data Collection of BWI}

At this stage the authors collect data to be used as the basis for the source of the problem or what is needed by the Indonesian waqf agency, data collection uses the interview method to ask details of the Indonesian waqf agency, which later the results of the interview will be attached to the research report.

\subsection{Planning for Platform BWI}

In this process, the process of designing a system is carried out, which is necessary to adjust, analyze the system requirements, which can be used according to user requirements. At this stage, we need an information system that can be built and easy to use according to user needs and can adapt to fast digital needs.

\subsection{Designing Implementation Project}

In this process, the authors make initial designs according to user requirements and translate them into visual UML diagrams such as use case diagrams, activity diagrams, and class diagrams. 
The design is made by adding the required features in order to make it easier to use. In designing, the authors work with users to see the progress of the system.

\subsection{Coding (Development Process)}

In this process the writer performs a coding system (software coding) by the programmer in accordance with the designs that have been made previously. In the construction management information system development stage, programmers can make changes to the information system quickly as desired by the user.

\subsection{Release}

In this process, the authors conduct software testing which is carried out on an ongoing basis in accordance with customer needs by using the principles of agile development. So in the release stage, the authors provide the software testing results to the main stakeholders in order to evaluate the usefulness of the system whether or not it is in accordance with the needs of the user (user requirements).

\subsection{Evaluation}

In this process the authors evaluate the system as a whole. Evaluation is carried out based on a functionality test by providing a questionnaire that represents the usability aspects, namely efficiency, effectiveness, and satisfaction.

\section{RESEARCH RESULT AND DISCUSSION}

\subsection{Data Collection and Analysis of Requirement System}

The activity of Nadhir registration services at the Indonesian Waqf Board is carried out offline by means that prospective Nadhir must come to the office to be able to register as nadhirs and registration is still using the manual system. A candidate Nadhir provides registration documents and requirements in the form of hardcopy to the office then the files are received by the secretary to be given a letter number after which the files are disposable to the Nadhir division to check the completeness of the files and verify the data. Prospective Nadhir who pass the verification will be invited to conduct interviews while Nadhir candidates who do not pass the verification will be asked to double-check the files. After conducting interviews, the Nadhir division provides recommendations for the Nadhir candidates to the leadership. If the leadership approves, the candidate of Nadhir receives a certificate.

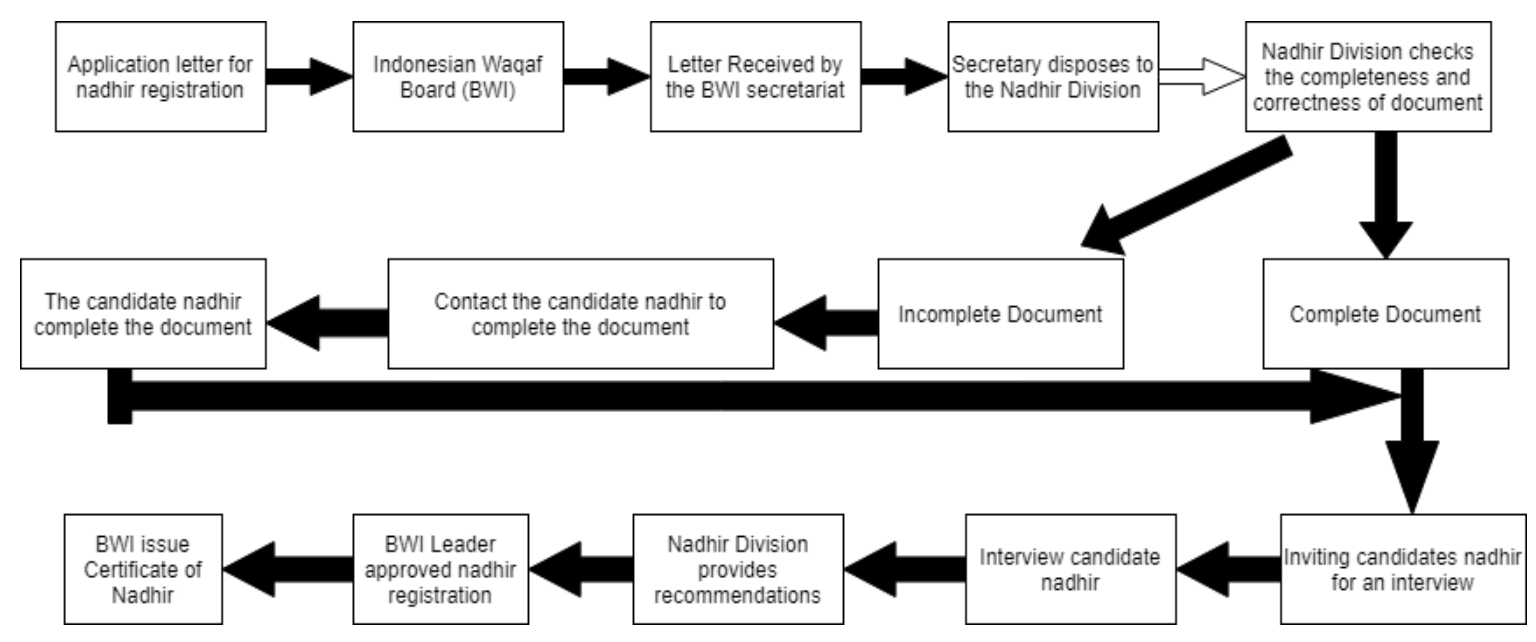

Figure 2. The activity of Nadhir Registration 


\subsubsection{Flowchart of the System}

The right solution in solving the existing problem is changing the Nadhir registration system which runs manually with a computerized website information system which is expected to help the Nadhir registration activity to be faster. In general, the system to be developed is the registration process for Nadhir, submitting files and requirements online, each candidate for Nahdir has a separate account to carry out the registration process. The system can inform the final data, process data, and print certificates automatically. The system flow can be seen in Figure 2 .

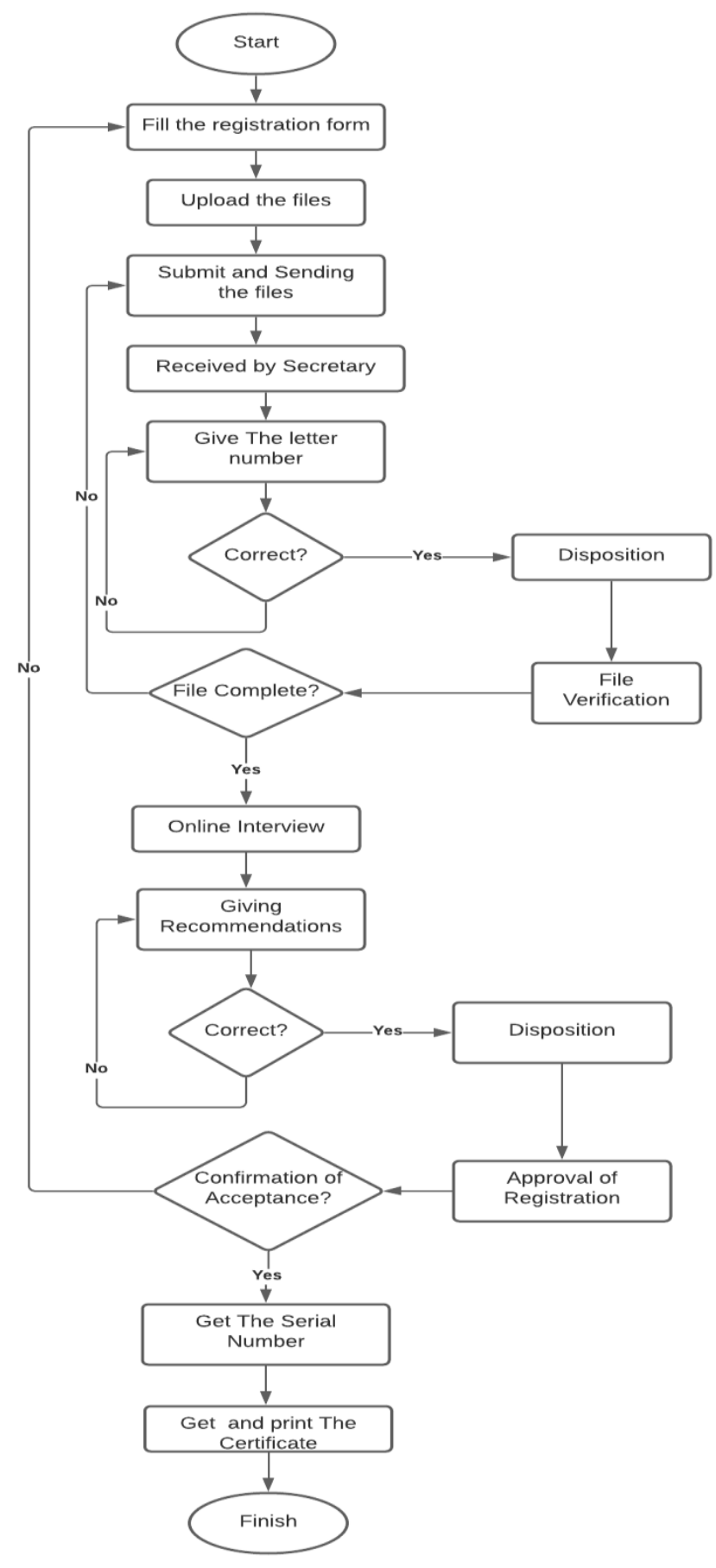

Figure 3. Flowchart of The System 


\subsubsection{Functional Requirements}

a. General Requirements

1. Nadhir candidate can register and log in into the candidate information system registration.

2. Nadhir candidates can register new cash waqf.

3. Nadhir candidates complete the requirements in registration, requirements

4. Candidate Nadhir sends application for registration to BWI.

5. The BWI Secretariat accepts applications for registration from Candidates for Nadhir.

6. The BWI Secretariat dispositions applications for registration to the Division Nadhir.

7. Nadhir Division sees the completeness of the requirements that have been uploaded by Candidate Nadhir. If complete and appropriate, Nadhir Division schedule for an interview. If it's not complete, Nadhir Division return the application for registration to the Candidate Nadhir to be equipped.

8. Having determined the interview schedule, Nadhir Division conducts interviews with Candidate Nadhir by generating considerations from the interviews conducted.

9. After the interview, Nadhir Division provides recommendations during the meeting complete.

10. The results of the complete meeting of the leadership give approval / rejection of application for registration of Candidate Nadhir.

11. If approved, then Nadhir Candidate will get an eSet Certificate. If rejected, then nominee Nadhir must fix the shortcomings of the refusal.

b. Identification of Actor

Table 1. Identification of Actor

\begin{tabular}{|l|l|l|}
\hline No & Actor & Description \\
\hline 1 & Super Admin & $\begin{array}{l}\text { Person who responsible for managing the overall } \\
\text { system. }\end{array}$ \\
\hline 2 & Candidate Nadhir & $\begin{array}{l}\text { Person who accesses he system via internet to } \\
\text { register as an online Nadhir }\end{array}$ \\
\hline 3 & Secretary & $\begin{array}{l}\text { Person who accesses the system to position } \\
\text { registration files to the nadhir division }\end{array}$ \\
\hline 4 & Nadhir Division & $\begin{array}{l}\text { Person who access the system to verify the data and } \\
\text { recommend a candidate of Nadhir. }\end{array}$ \\
\hline 5 & Leader & $\begin{array}{l}\text { Person who accesses the system to approve a } \\
\text { candidate Nadhir to become as Nadhir. }\end{array}$ \\
\hline
\end{tabular}

3.1.3 Non-functional Requirements

a. Provides easy of the use for the Nadhir registration information system on each system features.

b. This registration system can be easily accessed on all windows, linux, OS X as Operating System. 


\subsection{System Design}

\subsubsection{Use Case Diagram}

The use case diagram is a model for the behavior of the information system to be made. Use case describes an interaction between one or more actors with the information system to be created. In Figure 3, users can use the system after logging in.

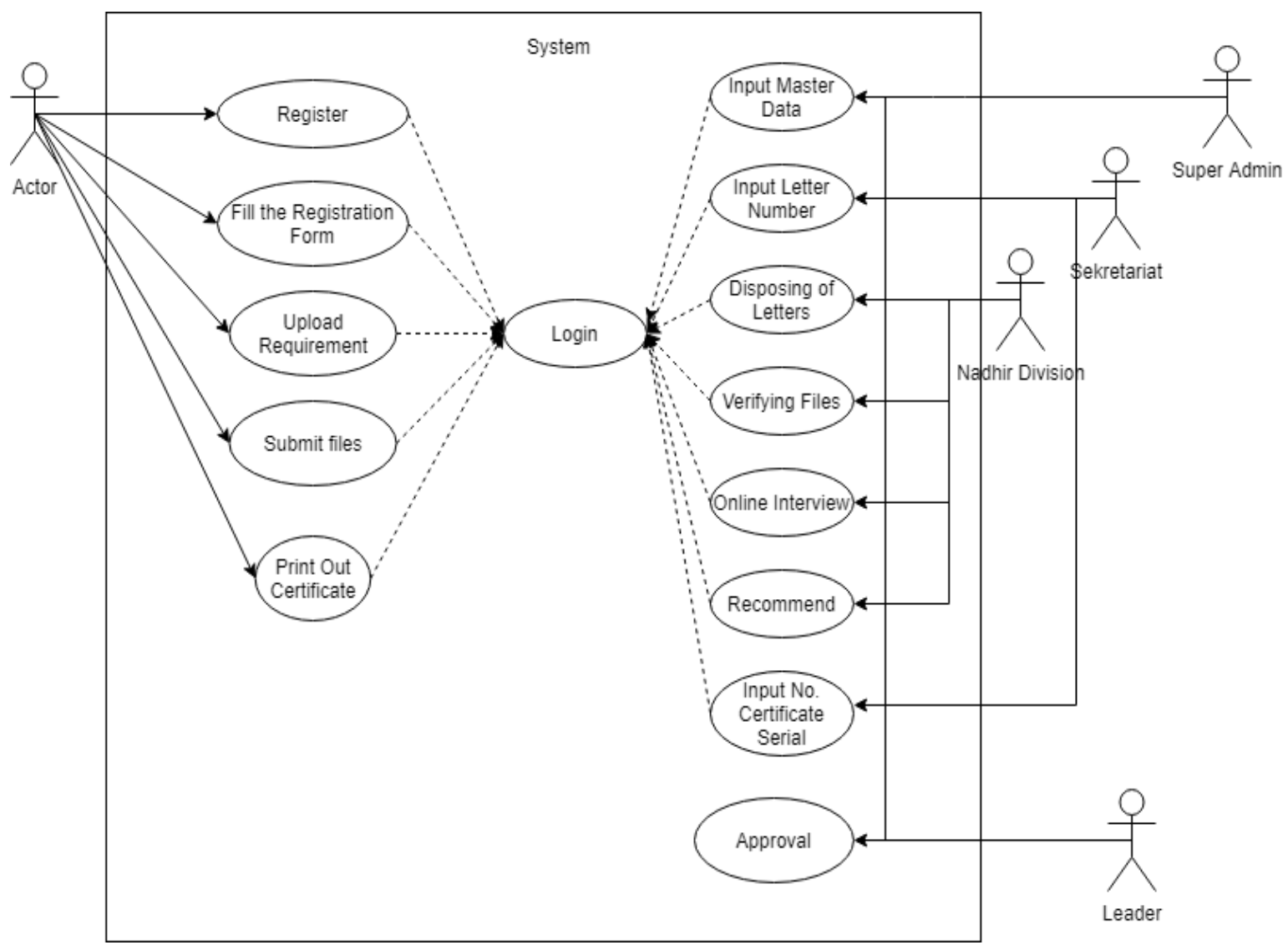

Figure 4. Use Case Diagram of Nadhir System Platform

\subsubsection{Class Diagram}

Class diagram is a diagram that shows the structural design of several existing classes of a system logically. Class diagrams describe the structure of the system in terms of defining classes that are made to build a system. Class has an attribute and method or operation. Attributes are variables owned by a class. Meanwhile, operations or methods are functions that belong to a class. Figure 5 is a class diagram of the Nadhir registration information system. 


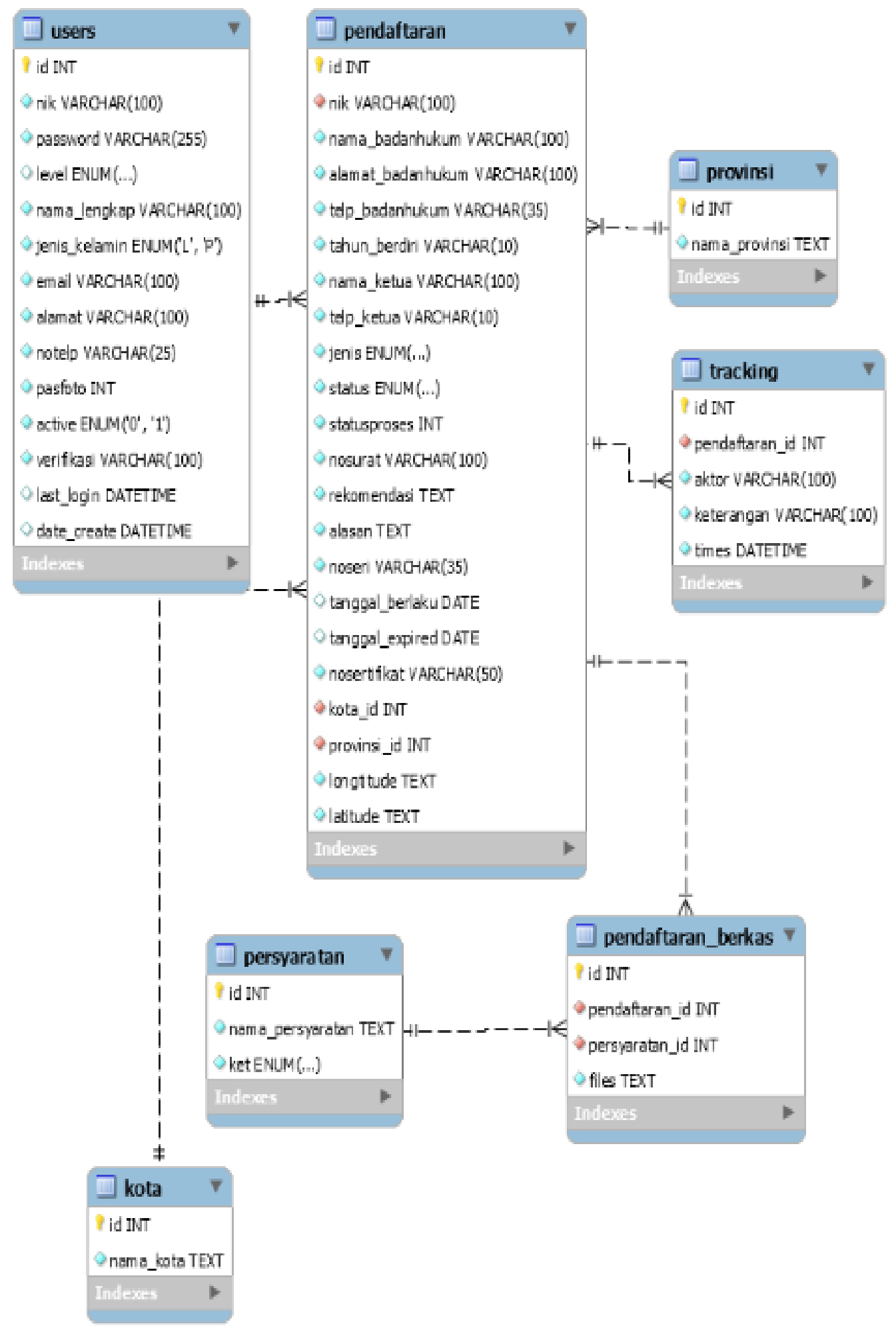

Figure 5. Class Diagram 


\subsection{Design Implementation}

\subsubsection{Register}

The register page is a feature for registering an account to register waqf registration. In registering, users are required to fill out a form registration consisting of email, password, KTP no, cellphone number, and input Captcha code.

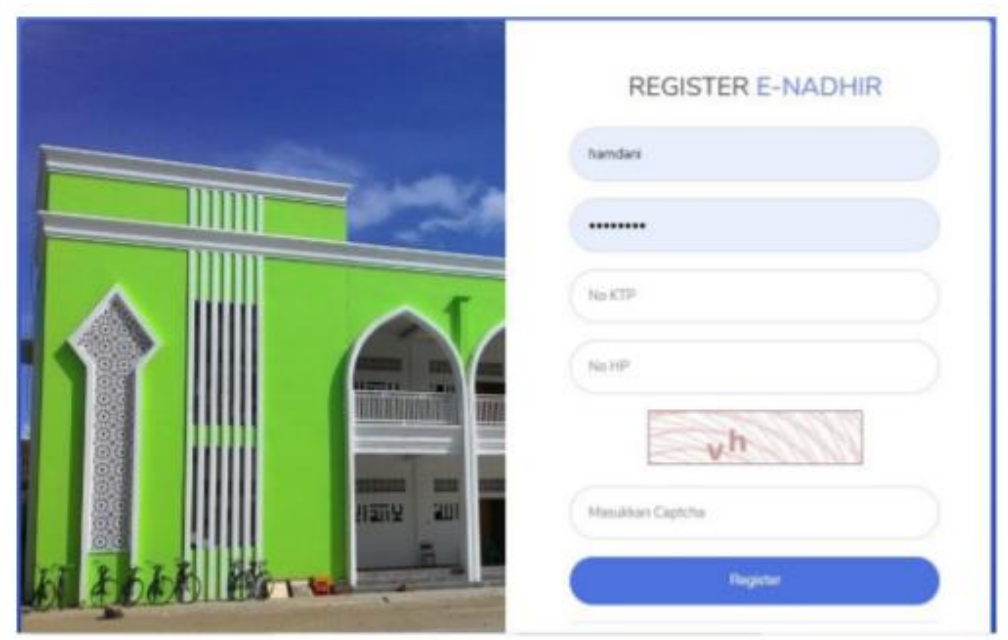

Figure 6. Register of E-Nadhir

\subsubsection{System Login}

The Login page is a feature to enter / log into the waqf registration system. In logging in, the user is required to fill in a login form consisting of a NIK, password.

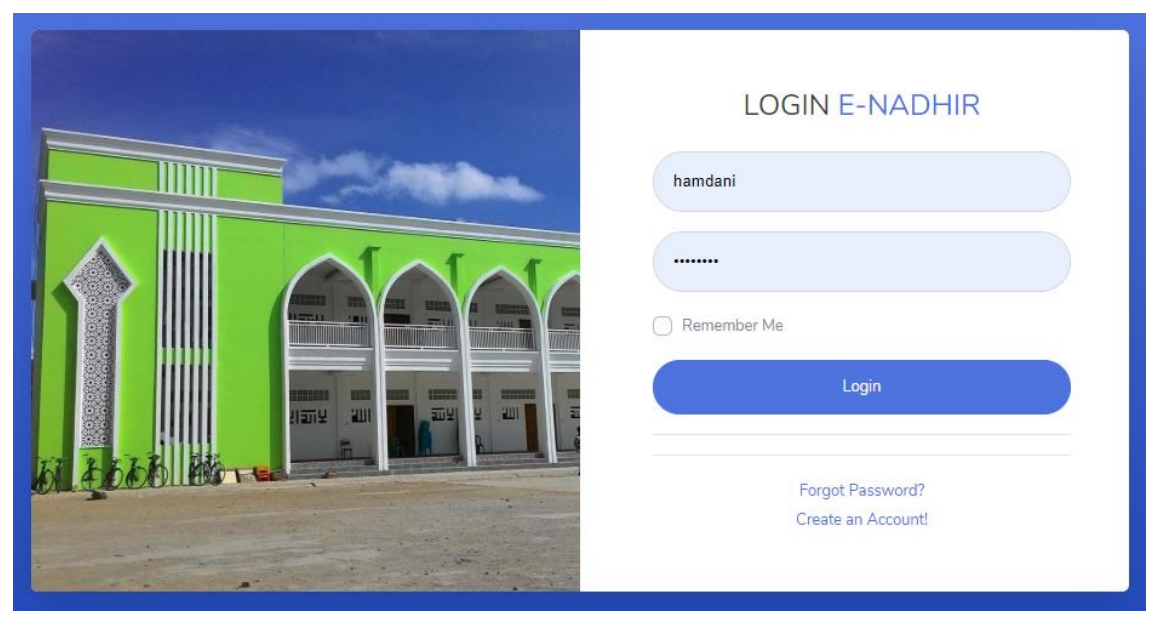

Figure 7. System Login of E-Nadhir

\subsubsection{Requirement Master}

The Requirement Master, including list of requirements, add requirements, edit requirements, and remove the requirements.

a. List of Requirements, Requirements list page is a page that contains a list of requirements. 


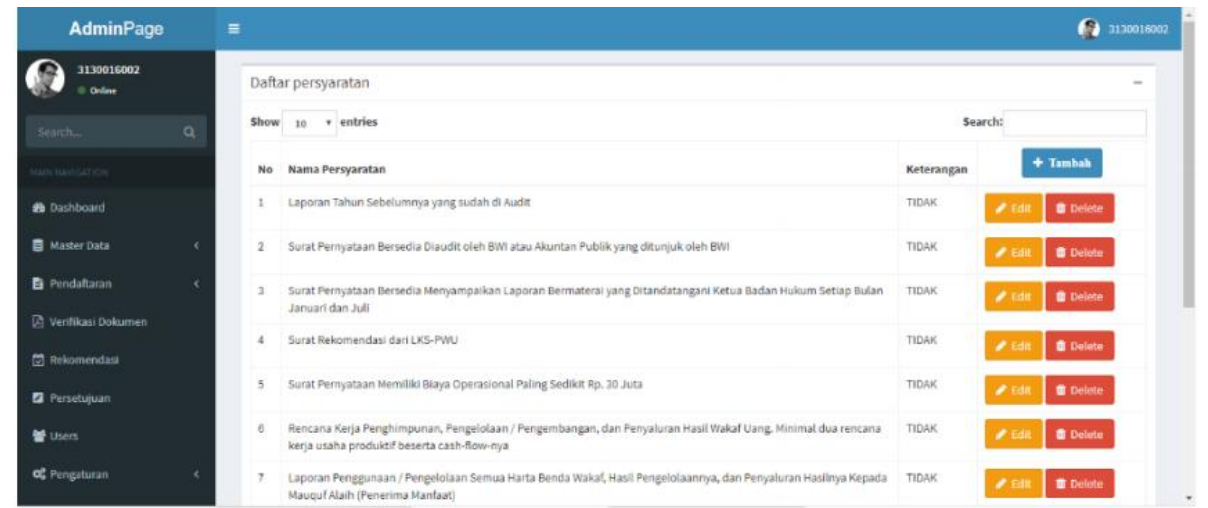

Figure 8. List Requirements

b. Add Requirements

If the candidate Nadhir want to add requirements press the add button, then fill out the requirement form which consists of the name of the requirement and information.

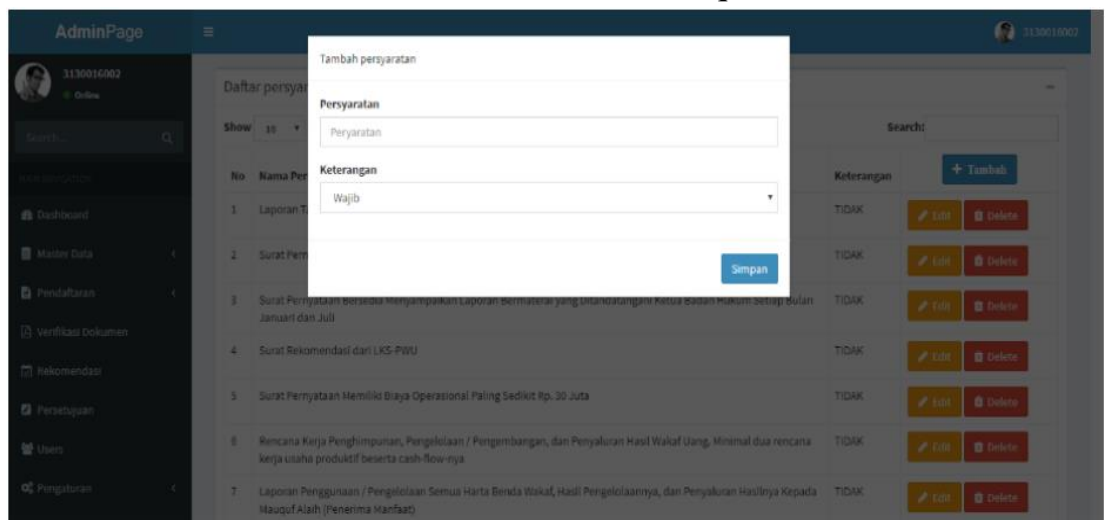

Figure 9. Add Requirements

c. Edit Requirements

If the candidate Nadhir want to change the requirements, press the edit button, then fill in the requirement edit form which consists of the name of the requirement and a description

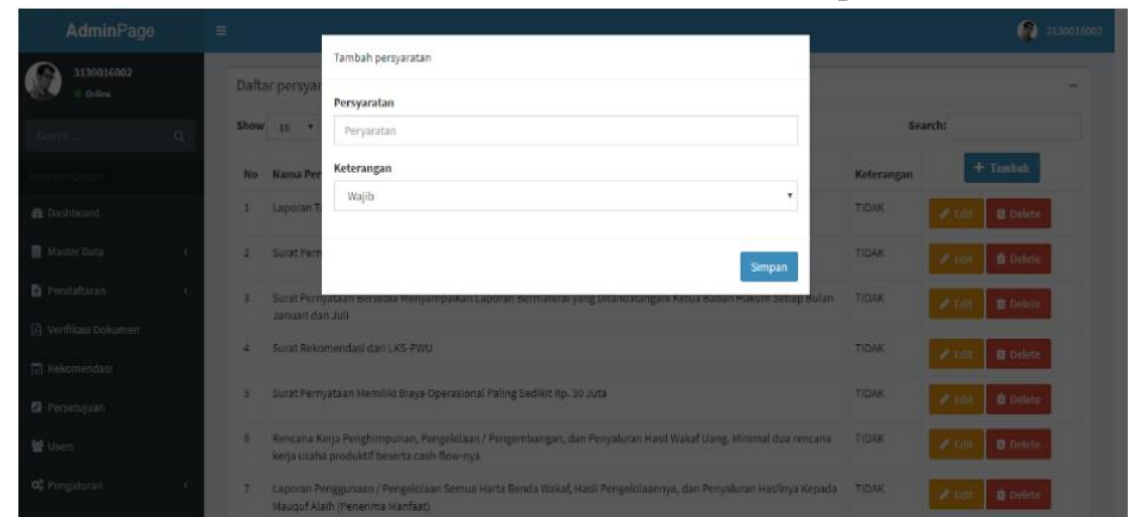

Figure 10. Edit Requirements

d. Remove Requirements

If the candidate Nadhir want to delete requirements, then click the delete button and the data will be deleted 


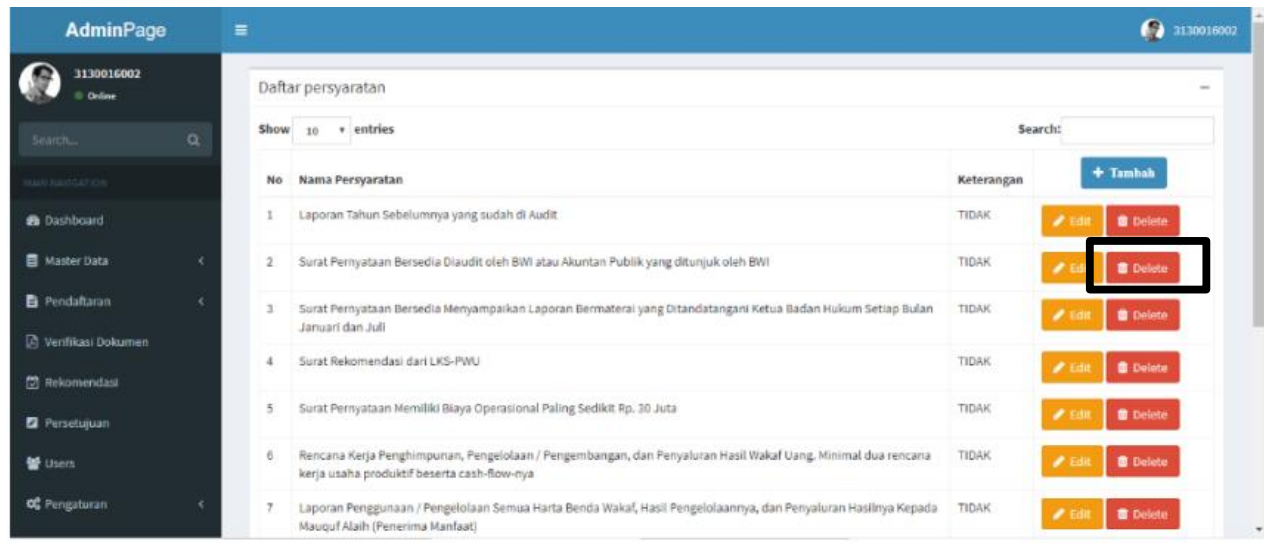

Figure 11. Remove Requirements

\subsubsection{Registration}

The Registration including registration list, add registration, edit registration, clear registration, upload files, sending files, input letter number, file verification, recommendation, approval, print certificate, and show the map location of the approval Nadhir.

a. Registration list, The registration list page is a page that contains a list Nadhir registration.

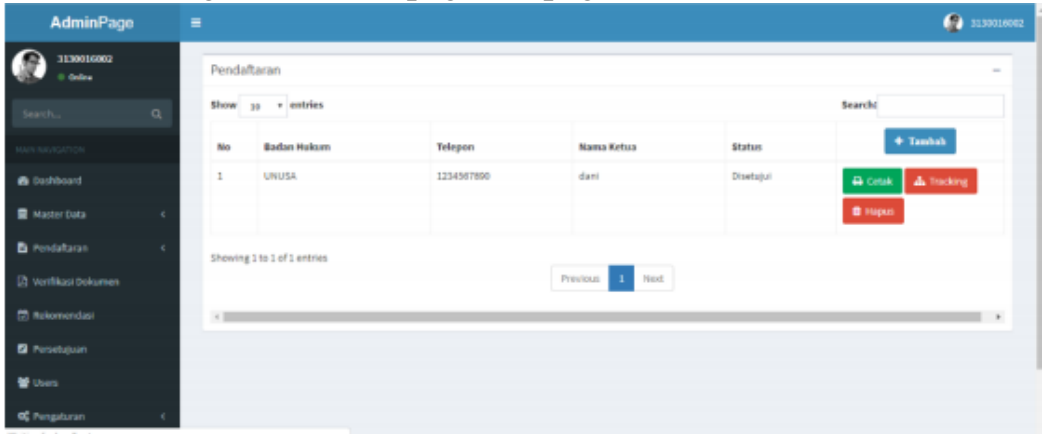

Figure 12. Registration list

b. Add Requirements

If the candidate Nadhir want to add a new registration, press the add button, then fill out the registration form consisting of the name of the legal entity, address, telephone number, year of establishment, longitude, latitude, name of the chairman, cellphone number, province, city.

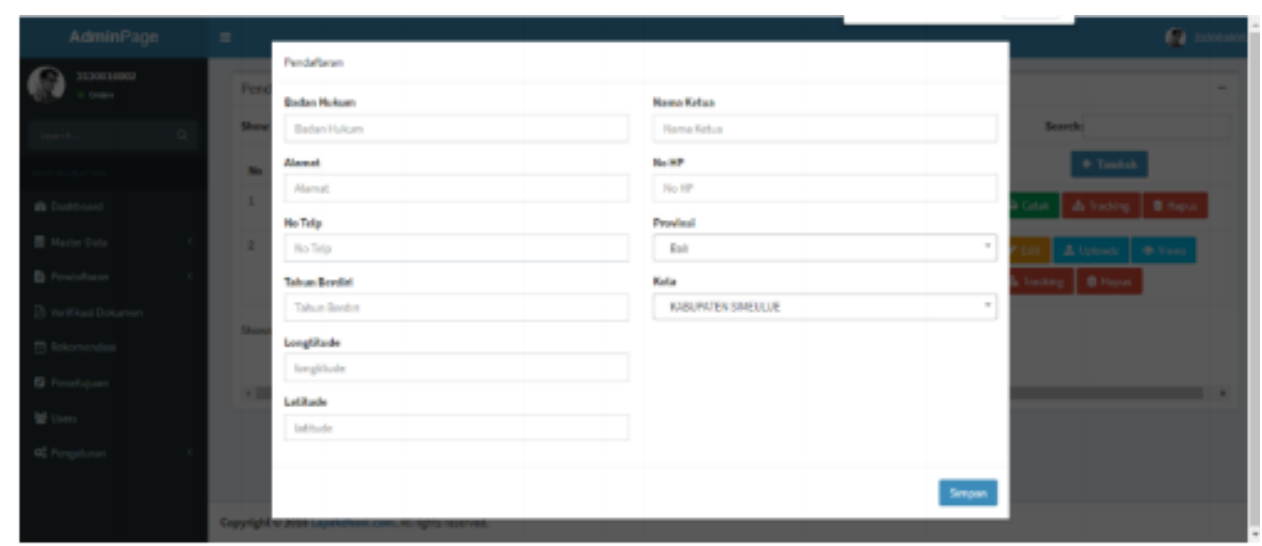

Figure 13. Add Registration 
c. Edit Registration

If the candidate Nadhir wants to edit the new registration, press the edit button, then fill in the registration edit form consisting of the name of the legal entity, address, telephone number, year of establishment, longtitude, latitude, name of the chairman, cellphone number, province, city.

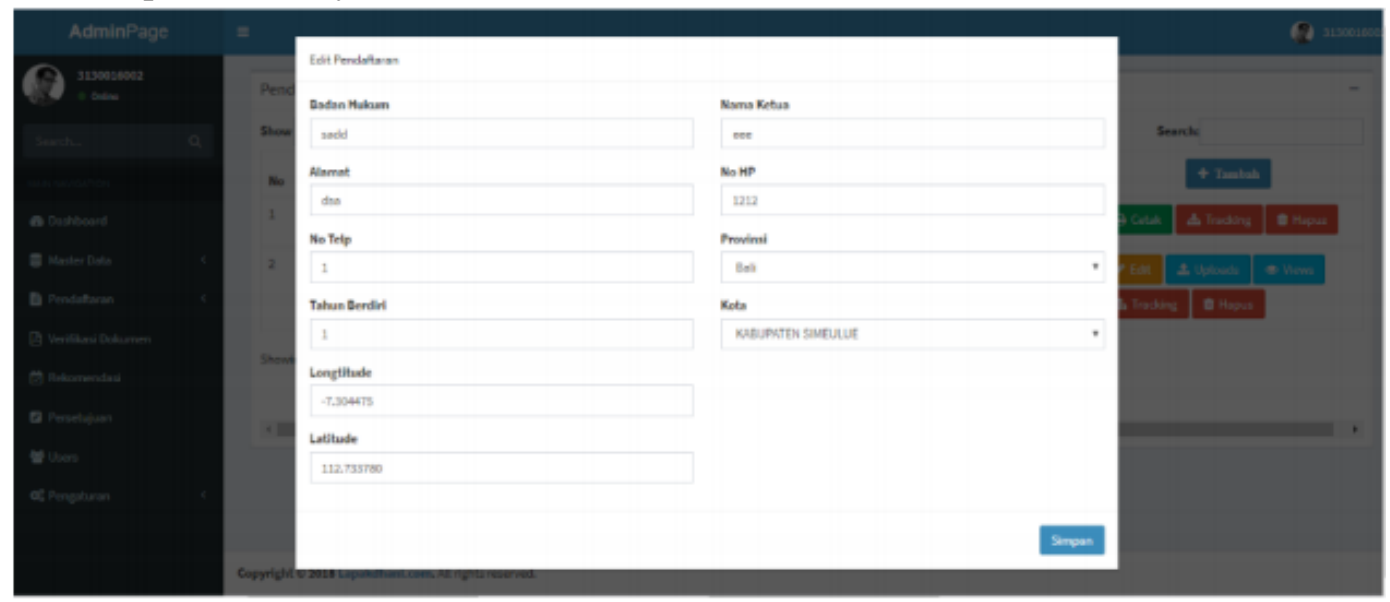

Figure 14. Edit Registration

d. Clear Registration

If the candidate Nadhir want to delete registration, click the delete button and the data will be deleted.

e. Upload Files

If the candidate Nadhir wants to upload the new registration file, press the upload button, then fill in the registration file upload form consisting of the file name and file uploads.

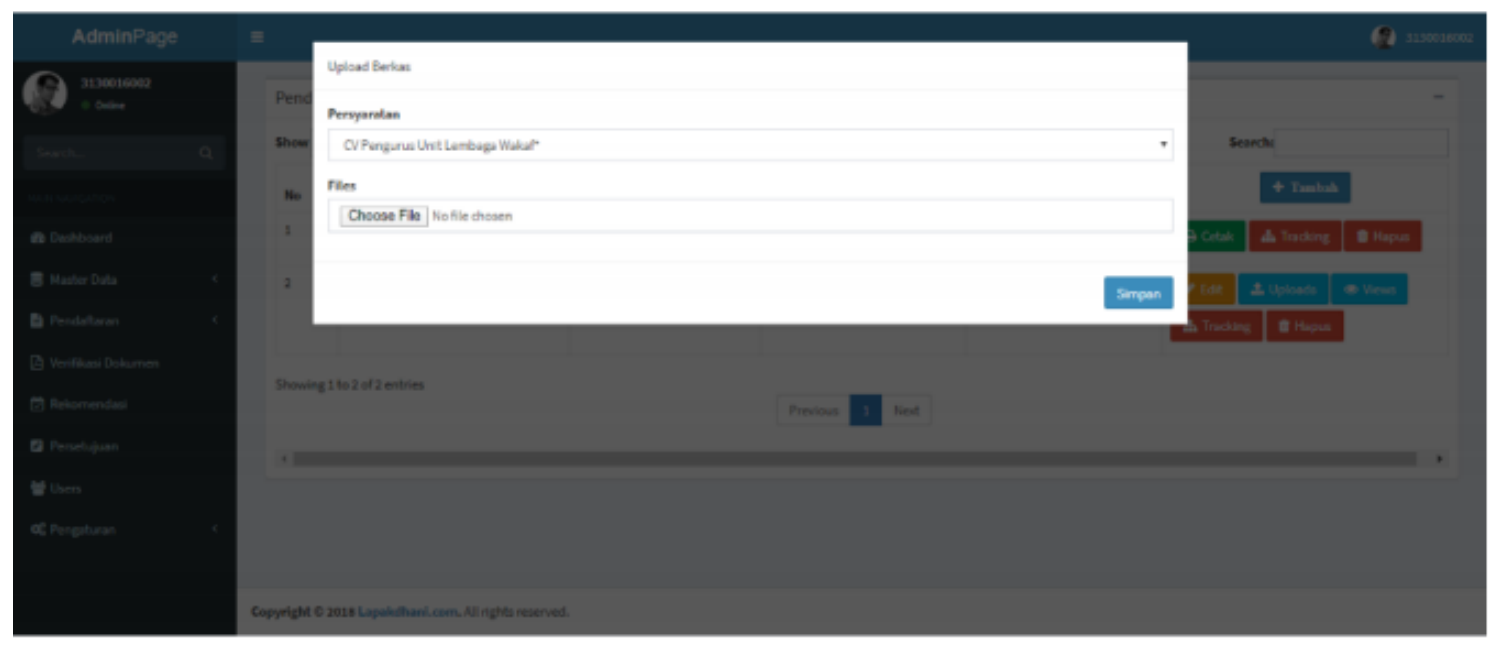

Figure 15. Upload File

f. Sending Files

Send registration files by clicking the submit button. 


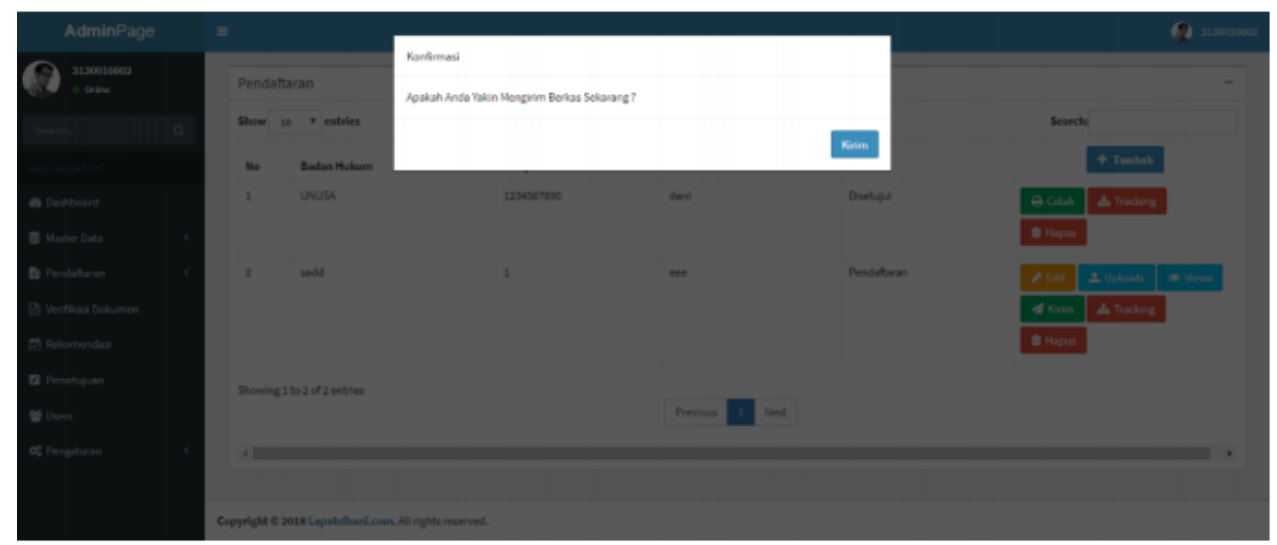

Figure 16. Sending Files

g. Input letter Number

After the file is sent the file is assigned a letter number by clicking the letter no. Button then filling out the letter no. Form then saved.

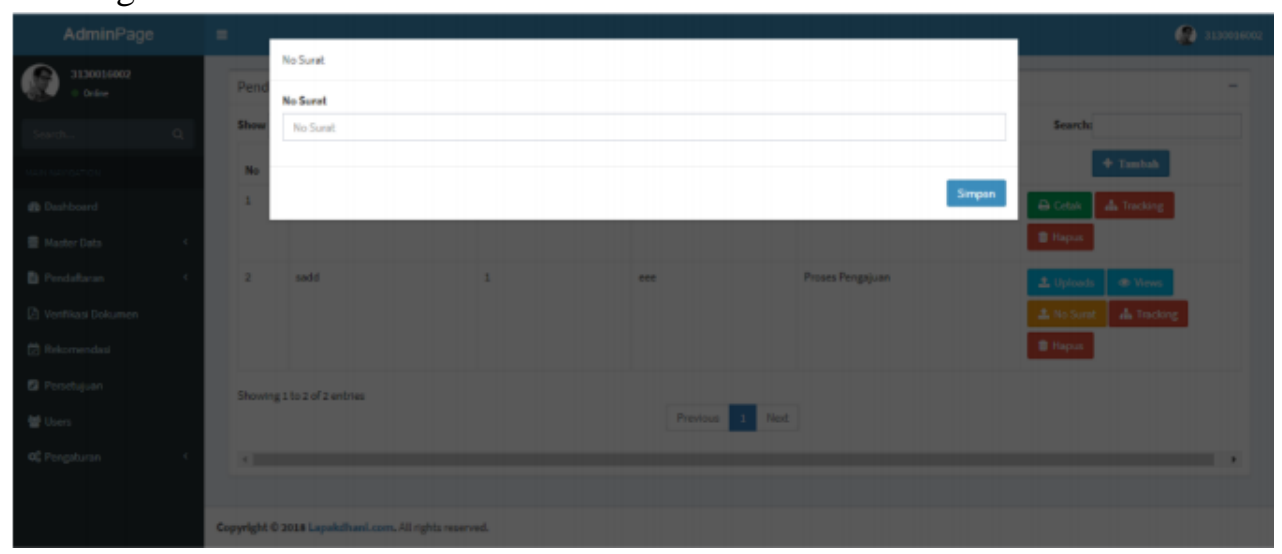

Figure 17. Input The Letter Number

h. File Verification

Verify the file by clicking the verification button

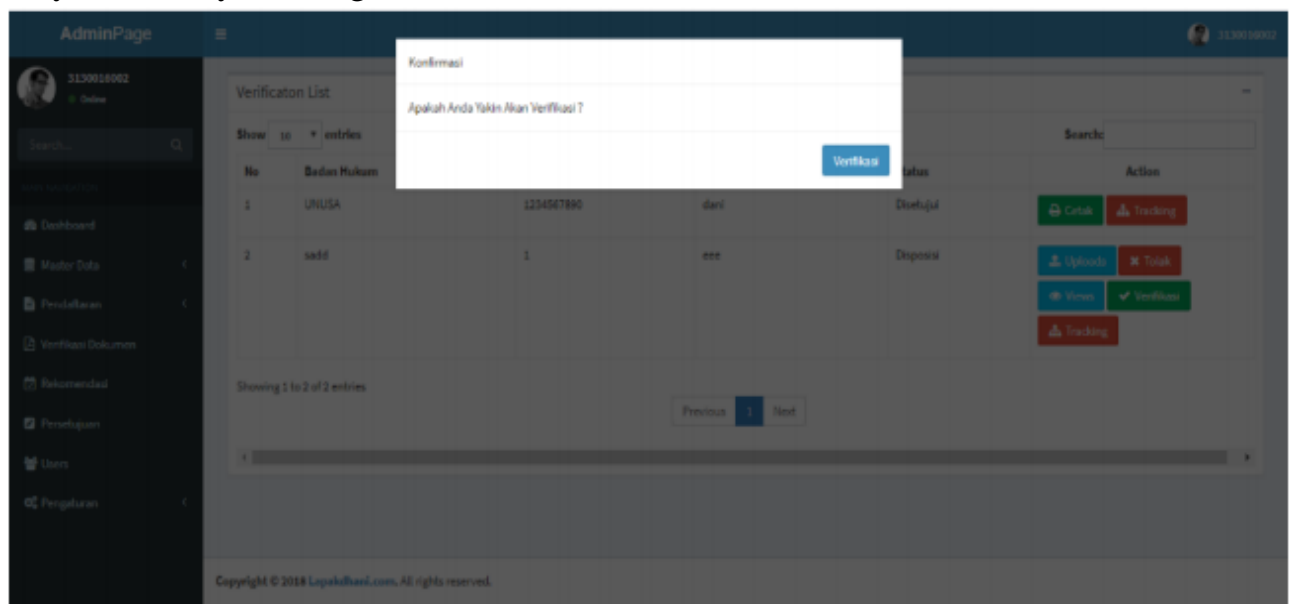

Figure 18. File Verification

i. Recommendation

Click the recommendation button, then fill out the recommendation form, then save it. 


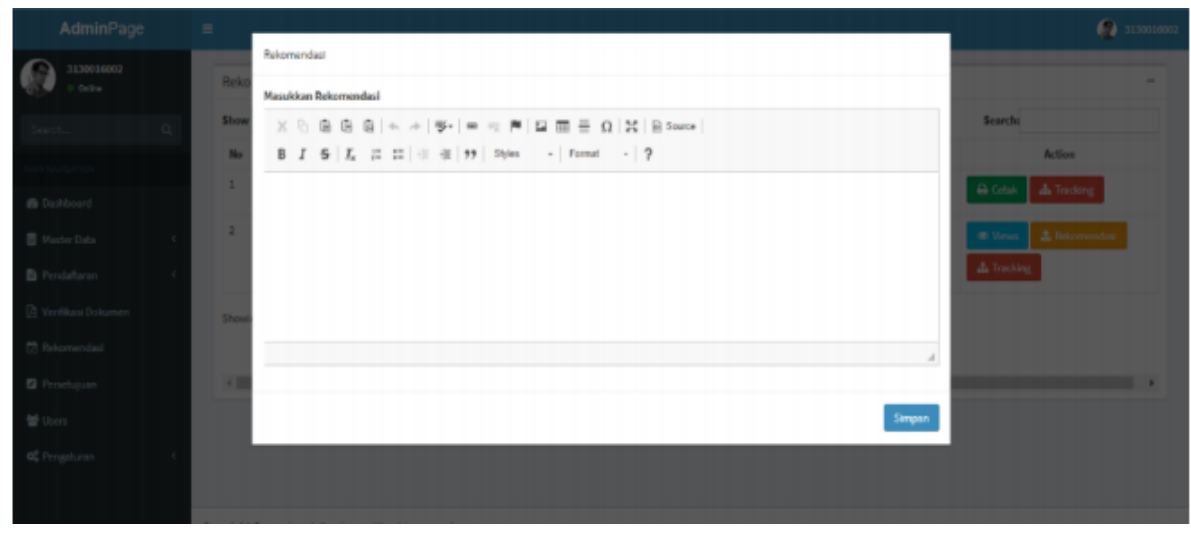

Figure 19. Recommendation

j. Approval

Click the approval button "Setuju" to accept the registration

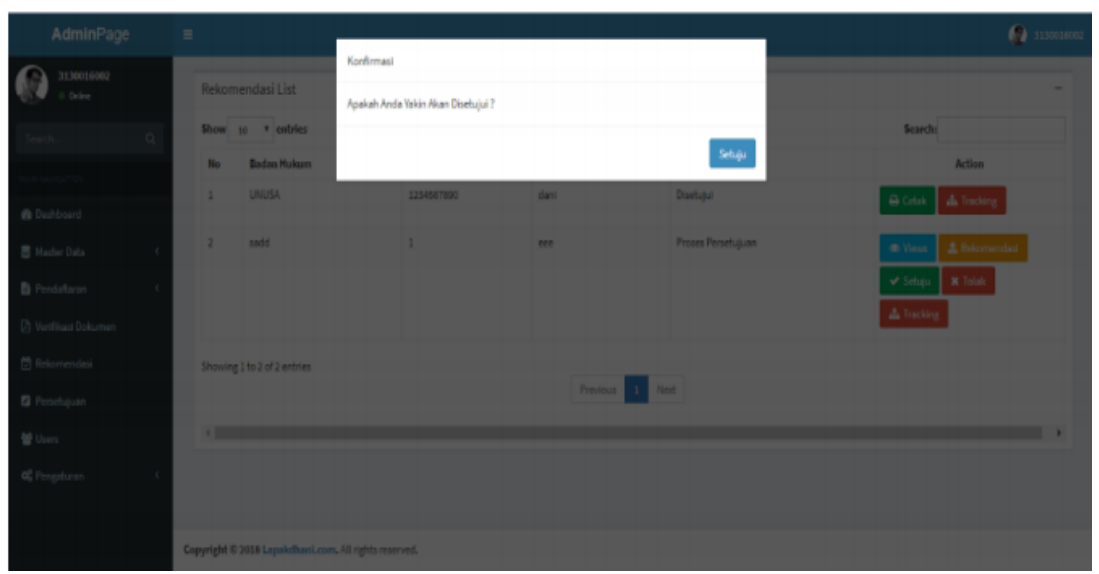

Figure 20. Approval

k. Print Certificate

Click Print certificate, then the certificate can be printed

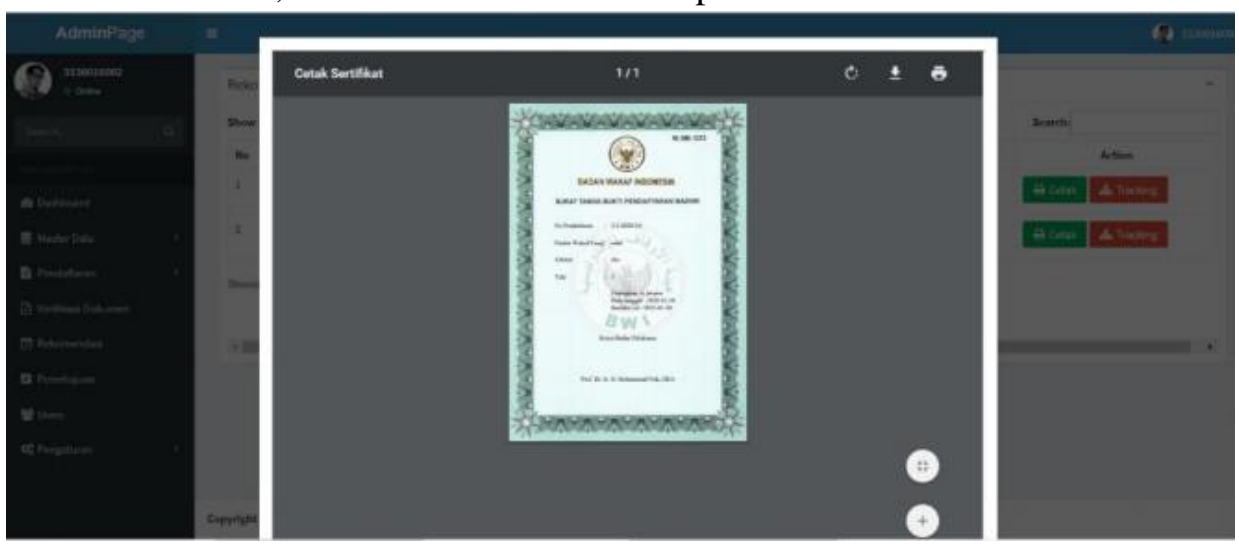

Figure 21. Print Certificate

1. Nadhir Data Location

The data report page shown the page that contains the map data of the Nadhir location that has been approved by the leadership 


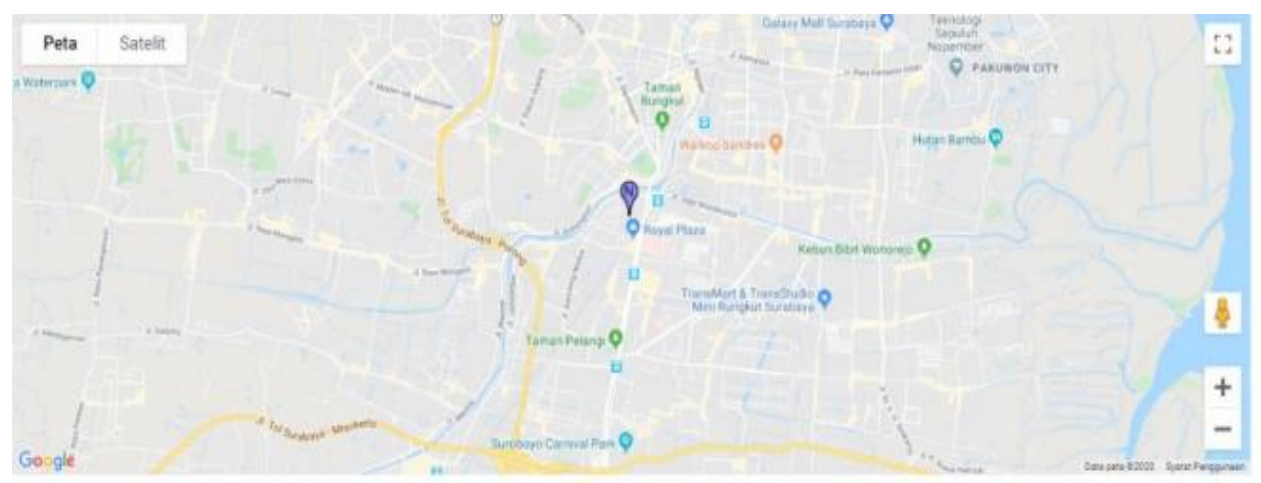

Figure 22. Nadhir Data Location

\subsection{Agile Implementation in System Development}

In the process of developing a Nadhir registration information system using Agile Development Methods to facilitate system development to achieve the results desired by the Indonesian Waqf Board. Agile implementation in the System Development Stage can be shown in Table 4.15

Table 2. Agile Implementation in System Development

\begin{tabular}{|c|c|c|c|}
\hline No & E-Nadhir & Stage & Result Description \\
\hline 1 & Planning & \multirow{4}{*}{1} & $\begin{array}{l}\text { Presenting the results of interviews with } \\
\text { the Indonesian waqf board coordinator }\end{array}$ \\
\hline 2 & Design Analysis & & $\begin{array}{l}\text { Present the results of use cases and } \\
\text { activity diagrams }\end{array}$ \\
\hline 3 & System Development & & $\begin{array}{l}\text { Shows the results of the system display } \\
\text { design, shows what menus are in the } \\
\text { system }\end{array}$ \\
\hline 4 & Testing & & $\begin{array}{l}\text { There are corrections to add the } \\
\text { information page / company profile } \\
\text { feature }\end{array}$ \\
\hline 5 & Design Analysis & \multirow{3}{*}{2} & $\begin{array}{l}\text { Shows the results of adding the revised } \\
\text { use case information page / company } \\
\text { profile such as add serial number and } \\
\text { print the certificate in time }\end{array}$ \\
\hline 6 & System Development & & $\begin{array}{l}\text { Shows the display page information / } \\
\text { company profile such as add serial } \\
\text { number and print the certificate in time }\end{array}$ \\
\hline 7 & Testing & & $\begin{array}{l}\text { There are corrections to add the final } \\
\text { data report feature in the form of maps }\end{array}$ \\
\hline 8 & Design Analysis & \multirow{3}{*}{3} & $\begin{array}{l}\text { Shows the results of adding the revised } \\
\text { use case information page / company } \\
\text { profile such as add data report with the } \\
\text { maps }\end{array}$ \\
\hline 9 & System Development & & $\begin{array}{l}\text { Shows the display page information / } \\
\text { company profile such as add data report } \\
\text { with the maps }\end{array}$ \\
\hline 10 & Testing & & $\begin{array}{l}\text { There is no other need correction and the } \\
\text { system can be used. }\end{array}$ \\
\hline
\end{tabular}




\subsection{Blackbox testing and Usability testing of E- Nadhir}

E-Nadhir application using blackbox testing and usability testing. The results show that every button and transition of the system in each page run appropriately. The results of black box testing of E-Nadhir applications are presented in detail in Table 3 and The result of usability testing can be shown in Table 4.

Table 3. The result of blackbox testing

\begin{tabular}{|c|c|c|}
\hline Page & Testing Button & Status \\
\hline \multirow{2}{*}{ Homepage } & View & $(\sqrt{ })$ Succeed $($ ) Failed \\
\hline & Edit & $(\sqrt{ })$ Succeed $(\mathrm{n})$ Failed \\
\hline \multirow[t]{2}{*}{ Registration Account } & Register & $(\sqrt{ })$ Succeed $(\mathrm{)})$ Failed \\
\hline & Verification & $(\sqrt{ })$ Succeed $(\mathrm{)})$ Failed \\
\hline Login & Verification & $(\sqrt{ })$ Succeed () Failed \\
\hline \multirow[t]{4}{*}{ Data Master } & View & $(\sqrt{ })$ Succeed $(\quad)$ Failed \\
\hline & Add & $(\sqrt{ })$ Succeed () Failed \\
\hline & Edit & $(\sqrt{ })$ Succeed () Failed \\
\hline & Delete & $(\sqrt{ })$ Succeed () Failed \\
\hline \multirow[t]{4}{*}{ Registration Nadhir } & View & $(\sqrt{ })$ Succeed () Failed \\
\hline & Add & $(\sqrt{ })$ Succeed () Failed \\
\hline & Edit & $(\sqrt{ })$ Succeed $(\mathrm{)}$ Failed \\
\hline & Delete & $(\sqrt{ })$ Succeed $(\quad)$ Failed \\
\hline \multirow[t]{2}{*}{ Input Letter Number } & View & $(\sqrt{ })$ Succeed $($ ) Failed \\
\hline & Edit & $(\sqrt{ })$ Succeed $(\quad)$ Failed \\
\hline \multirow[t]{2}{*}{ Disposition Files } & View & $(\sqrt{ })$ Succeed () Failed \\
\hline & Edit & $(\sqrt{ })$ Succeed () Failed \\
\hline \multirow[t]{2}{*}{ Verification Files } & View & $(\sqrt{ })$ Succeed () Failed \\
\hline & Edit & $(\sqrt{ })$ Succeed $(\mathrm{)})$ Failed \\
\hline \multirow[t]{2}{*}{ Rekomendation } & View & $(\sqrt{ })$ Succeed $($ Failed \\
\hline & Edit & $(\sqrt{ })$ Succeed () Failed \\
\hline \multirow[t]{2}{*}{ Approval } & View & $(\sqrt{ })$ Succeed () Failed \\
\hline & Edit & $(\sqrt{ })$ Succeed $(\quad)$ Failed \\
\hline \multirow[t]{3}{*}{ Print Certificate } & View & $(\sqrt{ })$ Succeed $($ ) Failed \\
\hline & Edit & $(\sqrt{ })$ Succeed () Failed \\
\hline & Print out & $(\sqrt{ })$ Succeed () Failed \\
\hline Data Laporan Nadhir & View & $(\sqrt{ })$ Succeed () Failed \\
\hline $\begin{array}{l}\text { Notification Error if registration nadhir not } \\
\text { complete }\end{array}$ & View & $(\sqrt{ })$ Succeed $(\quad)$ Failed \\
\hline
\end{tabular}

After completing all existing blackbox testing, the next step is Usability testing by distribute questionnaires to administrators, secretaries, Nadhir divisions, leaders and Nadhir candidates containing 18 statements that represent the three aspects of usability, namely efficiency, effectiveness and satisfaction [12]. Users fill out questionnaires that have distributed based on their experiences (what they saw and tried) when doing blackbox testing. 
Table 4. The Result of Usability Testing

\begin{tabular}{|c|c|c|c|c|c|c|c|c|c|c|c|c|c|c|c|c|c|c|c|}
\hline & \multicolumn{18}{|c|}{ Usability Question } & \multirow{2}{*}{ Total } \\
\hline $\mathrm{R}$ & 1 & 2 & 3 & 4 & 5 & 6 & 7 & 8 & 9 & 10 & 11 & 12 & 13 & 14 & 15 & 16 & 17 & 18 & \\
\hline R1 & 4 & 4 & 4 & 4 & 4 & 3 & 3 & 3 & 3 & 3 & 4 & 4 & 4 & 3 & 3 & 3 & 3 & 3 & 62 \\
\hline $\mathrm{R} 2$ & 5 & 4 & 5 & 4 & 4 & 4 & 4 & 4 & 4 & 4 & 5 & 4 & 5 & 5 & 5 & 4 & 4 & 5 & 79 \\
\hline R3 & 5 & 4 & 4 & 4 & 5 & 5 & 5 & 4 & 4 & 5 & 5 & 4 & 4 & 5 & 5 & 5 & 4 & 5 & 82 \\
\hline $\mathrm{R} 4$ & 4 & 4 & 4 & 4 & 5 & 4 & 4 & 5 & 5 & 5 & 5 & 4 & 4 & 4 & 4 & 4 & 4 & 4 & 77 \\
\hline R5 & 4 & 4 & 4 & 4 & 5 & 3 & 4 & 4 & 4 & 4 & 5 & 3 & 4 & 4 & 4 & 4 & 5 & 4 & 71 \\
\hline \multicolumn{19}{|c|}{ Total } & 371 \\
\hline \multicolumn{19}{|c|}{ Average } & 74.2 \\
\hline \multicolumn{19}{|c|}{ Procentage } & $82 \%$ \\
\hline
\end{tabular}

Based on the results of the evaluation, the Nadhir registration information system got an overall score of 371 with an overall average of 74.2 and an overall percentage of $82 \%$ so that the management information system in all aspects of the variables can be said to be very feasible for the Nadhir registration information system in the Indonesian waqf body.

\section{CONCLUSION}

Based on the results and discussion above, it can be concluded that the E- Nadhir registration information system is designed with the Mysql database and in the process of developing this Nadhir registration information system, it uses the agile development method to facilitate the development of the system to achieve the desired results by the Indonesian waqf agency.This registration information system application has an attractive and simple design to make it easier for users to use the system. The results based on experiment are in the form of a website-based nadhir registration information system that features online registration, file upload, disposition, file verification, recommendations, approving and printing certificates that can help the process of registering nadhir in Indonesian Waqf Board. The system test results obtained from the usability variable of $82 \%$ so it can be concluded that the system is feasible to use.

\section{REFERENCES}

[1] F. M. Harun, B. T. Possumah, M. H. B. M. Shafiai, and others, "Issues and economic role of waqf in higher education institution: Malaysian experience," Al-Iqtishad J. Ilmu Ekon. Syariah, vol. 8, no. 1, pp. 149-168, 2016.

[2] F. Medias, "Productive Waqf in the Perspective of Islamic Economics," JurnalEkonomi Islam La Riba. Yogjakarta UII, vol. 4, no. 1, pp. 69-84, 2010.

[3] M. A. M. Haneef, N. K. B. M. Kamil, and Q. Ayuniyyah, "Development of Waqf in Indonesia: the Swot Analysis of Indonesia Waqf Board (Bwi)," Al-Infaq J. Ekon. Islam, vol. 8, no. 2, pp. 136-150, 2017.

[4] R. S. Pressman and others, "A Practitioner's Approach,” Softw. Eng., 2007.

[5] S. Ashmore and K. Runyan, Introduction to agile methods. Addison-Wesley Professional, 2014.

[6] F. Prihatini, U. Hasanah, and Wirdyaningsih, Hukum Islam: zakat dan wakaf: teori dan prakteknya di Indonesia. Diterbitkan atas kerjasama Papas Sinar Sinanti dengan Badan Penerbit ..., 2005.

[7] A. Mulyanto, "Sistem Informasi konsep dan aplikasi," Yogyakarta: Pustaka Pelajar, vol. 1, pp. 1-5, 2009.

[8] H. M. Jogiyanto, Analisis dan Desain (Sistem Informasi Pendekatan Terstruktur Teori dan Praktek Aplikasi Bisnis). Penerbit Andi, 2017.

[9] R. P. N. Budiarti, J. Maulana, and S. Sukaridhoto, "Aplikasi DIY Smart Trash Berbasis IoT 
Open Platform," Appl. Technol. Comput. Sci. J., vol. 1, no. 2, pp. 93-104, 2018.

[10]S. Sukaridhoto, D. K. Basuki, H. Yulianus, and R. P. N. Budiarti, "Performance Evaluation of Integrated Deep Learning Web Platform for Dataset Training," Appl. Technol. Comput. Sci. J., vol. 2, no. 2, pp. 117-128, 2019.

[11]R. P. N. Budiarti, A. Tjahjono, M. Hariadi, and M. H. Purnomo, "Development of IoT for Automated Water Quality Monitoring System," in 2019 International Conference on Computer Science, Information Technology, and Electrical Engineering (ICOMITEE), 2019, pp. 211-216.

[12] J. R. Lewis, "IBM computer usability satisfaction questionnaires: psychometric evaluation and instructions for use," Int. J. Hum. Comput. Interact., vol. 7, no. 1, pp. 57-78, 1995. 